\author{
dr. Shailender Singh ${ }^{1}$ \\ Associate Professor \\ Department of International Finance \\ International College, I-Shou University \\ Taiwan
dr. Sladjana Cabrilo (Corresponding Author) ${ }^{2}$ Associate Professor
Department of International Business Administration International College, I-Shou University \\ Taiwan
}

\title{
ANALYSING THE EFFECT OF CRITICAL VARIABLES ON THE ECONOMIC GROWTH OF A DEVELOPING ECONOMY
}

\begin{abstract}
India has been one of the growing world economies over the last few decades, and one of the defining features of India's growth has been investment-led growth. India's sustained economic growth and increased competitiveness in manufacturing has been underpinned by a massive economic development due to various critical factors. In this context, an attempt has been made to focus on the role of these critical factors on the growth of GDP and the Indian economy. Although the paper examines these phenomena in the specific case of the Indian economy, the analysis has a much wider application, both for the economic policy and for the theories of growth and structural change.
\end{abstract}

Key words: India, Economic Development, GDP, Growth

1 reshu111us@yahoo.com, singh@isu.edu.tw

2 sladjana@isu.edu.tw, sladjanacabrilo@gmail.com 


\section{INTRODUCTION}

Since the last two decades, India's name has figured prominently amongst the list of emerging economies. After decades of slow growth, India entered into a new phase of economic reconstruction during the mid eighties and the nineties. In comparison to a measly $1 \%$ growth rate in the years following independence from the British Raj in 1947, Indian GDP per capita growth rate reached $1.5 \%$ in the eighties, still not quite up to the benchmark but not dismal either. The picture drastically changed in the nineties, when the growth rate of GDP per capita reached an average of 5\%, much beyond the benchmark and a small miracle on its own.

The Indian economy has emerged with remarkable rapidity from the slowdown caused by the global financial crisis of 2007-09. Growth was strong in 2010-11 with a rebound in agriculture and continued momentum in manufacturing, though there was a deceleration in services caused mainly by the deceleration in community, social, and personal services, reflecting the base effect of fiscal stimulus in the previous two years. There has been a deceleration in industry and manufacturing, as indicated by index of industrial production (IIP) data pertaining to November 2010 is a matter of some concern. However, buoyancy in other indicators of industrial performance and the short -run nature of the IIP slowdown suggest that the deceleration is more in the nature of road bumps than indication of any long-run problem. The medium-to long-run prospect of the economy, including the industrial sector, continues to be positive. On the demand side, a rise in savings and investment and pickup in private consumption have resulted in strong growth of the gross domestic product (GDP) at constant market prices at 9.7 per cent in 2010-11. A sequenced and gradual withdrawal of the monetary accommodation is helping contain inflationary pressures. Inflation which remained at elevated levels for a large part of the current fiscal was largely driven by food items, though the goods that were inflating at the start of the fiscal year were different from the goods for which prices are rising now. Notwithstanding the tightening money markets and moderate growth in deposits, the financial situation remained orderly with a pickup in credit growth, vibrant equity market and stable foreign exchange market. Though downside risks of global events, particularly movement in prices of commodities like crude oil (exacerbated by political turmoil in the Middle East), remain, the Indian economy is poised to further improve and consolidate in terms of key macroeconomic indicators.

During the immediate past three years, the Indian economy has been severely buffeted by, but has successfully withstood, two shocks in rapid 
succession: (a.) a collapse in world growth, finances, and trade with the onset of the global financial crisis in 2007-09 whose ripple effects continued into 2009-10 and persisted into 2010-11 (with fiscal stresses in Europe); and (b.) domestically, following a year of negative growth in agriculture and allied sectors in 2008-09, erratic monsoons resulted in a severe drought in 2009-10 and unseasonal late rains affecting the winter season crops in 2010-11.

This period of economic stress has severely tested citizens and policymakers alike. Yet the Indian economy is coming through with resilience and strength. While some clouds linger-such as continued high food inflation and a temporary slowdown in industrial growth the dynamism in overall growth is evident, even as a series of social protection measures have considerably strengthened the ability to withstand shocks. These results owe to the counter-cyclical macroeconomic policies, structural measures to promote growth, social spending to provide a stronger foundation to protect the poor and, as always with economic progress, some luck in the form of good weather and slow but steady recovery of the global economy. In each of these areas, enormous progress was made during this crisis, and valuable lessons learnt for the future.

Table 1.1: Growth in GDP at Factor Cost at 2004-2005 Prices (Per cent)

\begin{tabular}{|l|c|c|c|c|c|c|}
\hline & $\begin{array}{c}\mathbf{2 0 0 5}- \\
\mathbf{0 6}\end{array}$ & $\begin{array}{c}\mathbf{2 0 0 6} \\
\mathbf{0 7}\end{array}$ & $\begin{array}{c}\mathbf{2 0 0 7}- \\
\mathbf{0 8}\end{array}$ & $\begin{array}{c}\mathbf{2 0 0 8}- \\
\mathbf{0 9}^{\mathrm{PE}}\end{array}$ & $\begin{array}{c}\mathbf{2 0 0 9}- \\
\mathbf{1 0}^{\mathrm{QE}}\end{array}$ & $\begin{array}{c}\mathbf{2 0 1 0}- \\
\mathbf{1 1}^{\mathrm{AE}}\end{array}$ \\
\hline $\begin{array}{l}\text { Agriculture, Forestry \& } \\
\text { Fishing }\end{array}$ & 5.1 & 4.2 & 5.8 & -0.1 & 0.4 & 5.4 \\
\hline Mining \& Quarrying & 1.3 & 7.5 & 3.7 & 1.3 & 6.9 & 6.2 \\
\hline Manufacturing & 10.1 & 14.3 & 10.3 & 4.2 & 8.8 & 8.8 \\
\hline $\begin{array}{l}\text { Electricity, Gas \& Waster } \\
\text { Supply }\end{array}$ & 7.1 & 9.3 & 8.3 & 4.9 & 6.4 & 5.1 \\
\hline Construction & 12.8 & 10.3 & 10.7 & 5.4 & 7.0 & 8.0 \\
\hline $\begin{array}{l}\text { Trade, Hotels, Transport \& } \\
\text { Communication }\end{array}$ & 12.1 & 11.7 & 10.7 & 7.6 & 9.7 & 11.0 \\
\hline $\begin{array}{l}\text { Financing, Insurance, Real } \\
\text { Estate \& Business Services }\end{array}$ & 12.7 & 14.0 & 11.9 & 12.5 & 9.2 & 10.6 \\
\hline $\begin{array}{l}\text { Community, Social \& Personal } \\
\text { Services }\end{array}$ & 7.0 & 2.9 & 6.9 & 12.7 & 11.8 & 5.7 \\
\hline GDP at Factor Cost & 9.5 & 9.6 & 9.3 & 6.8 & 8.0 & 8.6 \\
\hline
\end{tabular}

Source: Economic Survey of India, 2011. E: Provisional Estimates, QE: Quick estimates, AE: GDP figures for 2010-11 are advance estimates

The estimated level of growth in the GDP at constant 2004-05 prices at factor cost (real GDP) in 2010-11 was composed of: growth of 5.4 per cent in agriculture, which rebounded from a downturn in the previous year; growth of 
8.1 per cent in industry, which had a growth of 8.0 per cent in 2009-10; and a decelerated growth of 9.6 per cent in services as against 10.1 per cent in 2009-10 (Table 1.1). On the demand side, the GDP at constant prices (2004-05) at market prices is estimated to grow by 9.7 per cent. Four distinct facts emerge out of the recent macroeconomic data. First, adjusted for the base effect on community, social, and personal services, the services sector with a share of 57.3 per cent in 2009-10 has finally started to gather momentum and given the fact that it has been the power house of the Indian growth story, this portends well for the medium-term prospects. Second, the savings rate has gone up to a level of 33.7 per cent and investment rate is up to 36.5 per cent of the GDP in 2009-10, which, given the incremental capital-output ratio of about 4 , indicates prospects of sustained output growth. Third, there is a marked deceleration in industry as per recent monthly IIP data, decline in imports and signs of headline inflation remaining at elevated levels given the geopolitical risks in Middle East. All these could have implications for slowing down the momentum albeit in the short run. Fourth, fiscal policy is on the consolidation path with revenues doing well on the strength of the rebound in economic activity and, going forward, this is likely to yield growth dividends in the medium to long term setting in motion a virtuous cycle.

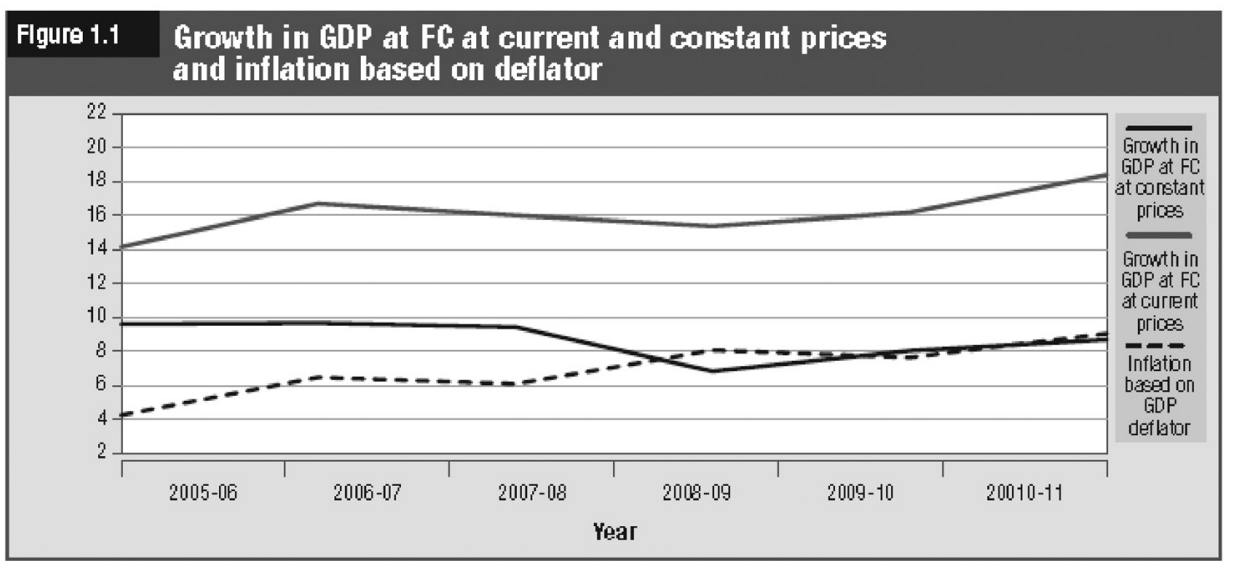

Source: $h t t p: / / i n d i a b u d g e t . n i c . i n$ 


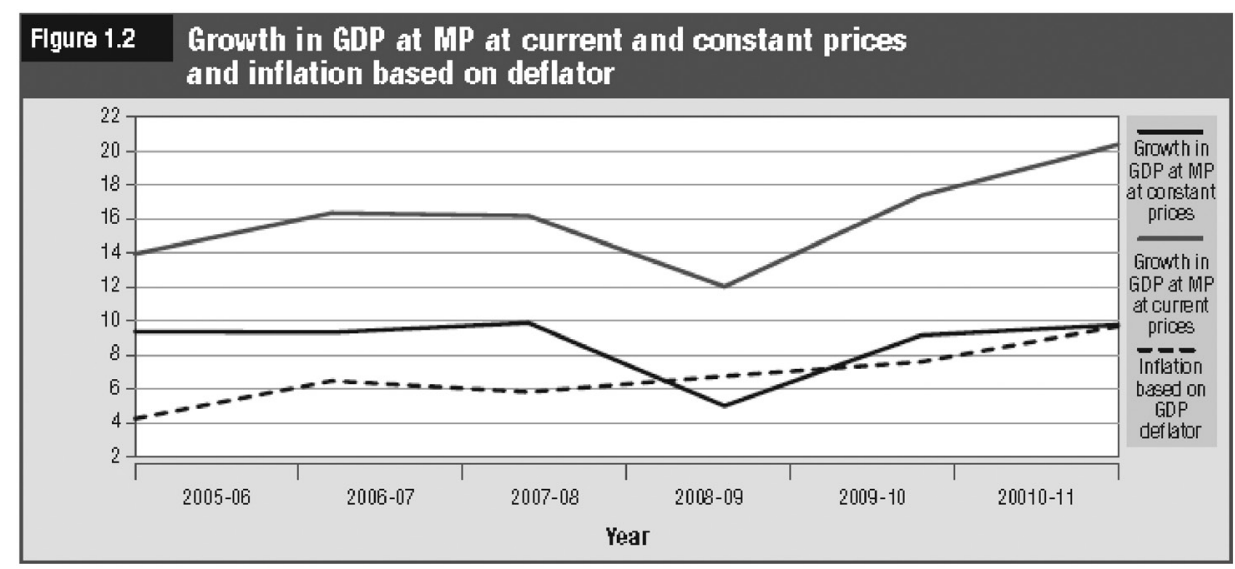

Source: http://indiabudget.nic.in

Agriculture and allied activities were estimated to have grown by 17.3 per cent in terms of current prices in Quick Estimates 2009-10 (as against 11.8 per cent in Revised Estimates 2009-10). With growth in terms of constant prices at 0.4 per cent, the implicit inflation is placed at 16.8 per cent. In so far as the growth rates in industry are concerned, the revision was smaller and the implicit inflation is placed at 2.8 per cent in 2009-10. In services as per the revisions in growth in current and constant prices implicit inflation of 7.6 per cent in 2009-10 is indicated (3.8 per cent as per the Revised Estimates). The level of inflation as measured by the implicit GDP deflator have risen resulting in widening of the differential in growth between current and constant prices for key macroeconomic indicators (Figures 1.1 and 1.2 ).

\section{AGGREGATE DEMAND AND ITS CONSUMPTION}

Table 1.2: Growth in GDP at Constant Market Prices

\begin{tabular}{|l|l|c|c|c|c|c|c|}
\hline & & $\begin{array}{c}\mathbf{2 0 0 5 -} \\
\mathbf{0 6}\end{array}$ & $\begin{array}{c}\mathbf{2 0 0 6} \\
\mathbf{0 7}\end{array}$ & $\begin{array}{c}\mathbf{2 0 0 7}- \\
\mathbf{0 8}\end{array}$ & $\begin{array}{c}\mathbf{2 0 0 8}- \\
\mathbf{0 9}^{\mathrm{PE}}\end{array}$ & $\begin{array}{c}\mathbf{2 0 0 9}- \\
\mathbf{1 0}^{\mathrm{QE}}\end{array}$ & $\begin{array}{c}\mathbf{2 0 1 0} \\
\mathbf{1 1}^{\mathrm{AE}}\end{array}$ \\
\hline \multirow{2}{*}{$\mathbf{1}$} & $\begin{array}{l}\text { Total final consumption } \\
\text { expenditure }\end{array}$ & 8.6 & 7.6 & 9.3 & 8.2 & 8.7 & 7.3 \\
\cline { 2 - 8 } \\
$\begin{array}{l}\text { 1.1 Private final consumption } \\
\text { expenditure }\end{array}$ & 8.5 & 8.3 & 9.3 & 7.7 & 7.3 & 8.2 \\
$\begin{array}{l}1.2 \text { Government final } \\
\text { consumption expenditure }\end{array}$ & 8.9 & 3.7 & 9.5 & 10.7 & 16.4 & 2.6 \\
\hline
\end{tabular}




\begin{tabular}{|l|l|c|c|c|c|c|c|}
\hline \multirow{3}{*}{ 2. } & Gross capital formation & 16.3 & 15.3 & 17.2 & -3.1 & 13.8 & 8.8 \\
\cline { 2 - 8 } & $\begin{array}{l}\text { 2.1 Gross fixed capital } \\
\text { information }\end{array}$ & 16.2 & 13.8 & 16.2 & 1.5 & 7.3 & 8.4 \\
\cline { 2 - 8 } & 2.2 Changes in stocks & 26.9 & 31.5 & 31.1 & -48.6 & 90.8 & 7.1 \\
\cline { 2 - 8 } & 2.3 Valuables & -1.4 & 13.7 & 2.8 & 26.9 & 54.2 & 19.5 \\
\hline \multirow{3}{3}{ 4. } & Exports & 25.8 & 20.0 & 5.9 & 14.4 & -5.5 & 12.0 \\
\hline \multirow{2}{*}{ 5. } & Less Imports & 32.5 & 21.3 & 10.2 & 22.7 & -1.8 & 6.3 \\
\cline { 2 - 8 } & $\begin{array}{l}\text { Growth in GDP at 2004-05 } \\
\text { market prices }\end{array}$ & 33.6 & 35.5 & 124.8 & -140.9 & -133.6 & -220.2 \\
\hline
\end{tabular}

Source: Economic Survey of India, 2011.

The expenditure estimates of the GDP (at constant market prices) reveal the dimensions of the impact of the global crisis on the Indian economy. Though the crisis deepened only in the second half of 2008-09, the demand-side GDP grew at much lower levels than the supply-side GDP (at constant prices at factor cost) on quarterly basis and year-on-year it was placed at one-half the levels of 2007-08. The deceleration in growth in private final consumption expenditure was lower in 2008-09 than reported earlier; the fiscal stimulus was only moderate with growth in Government final consumption expenditure at 10.7 per cent in 200809 (as against 16.7 per cent in the Quick Estimates of 2008-09). The real impact of the fiscal stimulus measures was felt in 2009-10 with a growth in Government final consumption expenditure at 16.4 per cent. Gross capital formation was estimated to have fallen sharply in 2008-09 and recovered equally sharply in 2009-10, mainly attributable to change in stocks. Growth in exports was also revised downwards for 2008-09 and 2009-10. Imports were also estimated to have declined only marginally by 1.8 per cent as against 17.2 per cent indicated in the Advance Estimates.

Demand-side GDP as measured at constant market prices is estimated to grow by 9.7 per cent in 2010-11 (Table 1.2); in terms of current market prices (nominal GDP) it is placed at 20.3 per cent. At constant market prices, while total consumption expenditure and capital formation are estimated to decelerate year-on-year in 2010-11, with private final consumption expenditure picking up, Government final consumption expenditure decelerating sharply owing to base effect and a pickup in gross fixed capital formation and net exports compositionally positive shifts are indicated. Inflation measured by the GDP deflator implicit in the demand- side estimates for 2010-11 is at 9.6 per cent. Similar estimates based on the levels of growth in the GDP at factor cost at constant and current prices was at 9.0 per cent. 
Table 1.3 : Demand side growth of GDP, Growth Contribution and Relative Share at 2004-05 Market Prices (per cent)

\begin{tabular}{|c|c|c|c|c|c|c|}
\hline & $\begin{array}{c}2004- \\
05 \\
\end{array}$ & $\begin{array}{c}2005- \\
06 \\
\end{array}$ & $\begin{array}{c}2006- \\
07 \\
\end{array}$ & $\begin{array}{c}2007- \\
08 \\
\end{array}$ & $\begin{array}{c}2008- \\
09 \\
\end{array}$ & 2009-10 \\
\hline GDP at Market Prices & - & 9.3 & 9.3 & 9.8 & 4.9 & 9.1 \\
\hline Consumption (Private) & - & 8.5 & 8.3 & 9.3 & 7.7 & 7.3 \\
\hline Consumption (Govt) & - & 8.9 & 3.7 & 9.5 & 10.7 & 16.4 \\
\hline $\begin{array}{l}\text { Gross Fixed Capital } \\
\text { Formation }\end{array}$ & - & 16.2 & 13.8 & 16.2 & 1.5 & 7.3 \\
\hline Changes in Stocks & - & 26.9 & 31.5 & 31.1 & -48.6 & 90.8 \\
\hline Exports & - & 25.8 & 20.0 & 5.9 & 14.4 & -5.5 \\
\hline Imports & - & 32.5 & 21.3 & 102.2 & 22.7 & -1.8 \\
\hline \multicolumn{7}{|l|}{ Contribution to Growth } \\
\hline Consumption (Private) & - & 54.2 & 52.5 & 54.9 & 90.5 & 47.8 \\
\hline Consumption (Govt) & - & 10.4 & 4.4 & 10.0 & 22.3 & 19.6 \\
\hline Gross Capital Formation & - & 57.3 & 50.4 & 67.2 & -44.3 & 72.3 \\
\hline $\begin{array}{l}\text { Gross Fixed Capital } \\
\text { Formation }\end{array}$ & - & 49.9 & 45.5 & 52.4 & 10.4 & 26.2 \\
\hline Net Exports & - & -186.6 & -10.2 & -13.6 & -57.6 & -8.0 \\
\hline \multicolumn{7}{|l|}{ Relative Share } \\
\hline Consumption (Private) & 59.1 & 58.7 & 58.2 & 57.9 & 59.4 & 58.5 \\
\hline Consumption (Govt) & 10.9 & 10.9 & 10.3 & 10.3 & 10.9 & 11.6 \\
\hline Gross Capital Formation & 32.8 & 34.9 & 36.2 & 39.0 & 35.1 & 38.2 \\
\hline $\begin{array}{l}\text { Gross Fixed Capital } \\
\text { Formation }\end{array}$ & 28.7 & 30.5 & 31.8 & 33.6 & 32.5 & 32.0 \\
\hline
\end{tabular}

Source: Economic Survey of India, 2011.

The levels of shares and contribution to growth of key demand-side aggregates do indicate that in 2008-09, the demand slowdown was largely explained by gross capital formation and net exports (Table 1.3). 
Table 1.4: Private Final Consumption-Annual Growth and Share at 2004-05 Prices

\begin{tabular}{|c|c|c|c|c|c|c|}
\hline & 2004-05 & 2005-06 & 2006-07 & 2007-08 & $\begin{array}{c}2008- \\
09^{\mathrm{PE}} \\
\end{array}$ & $\begin{array}{c}2009- \\
10^{\mathrm{QE}}\end{array}$ \\
\hline & & \multicolumn{5}{|c|}{ Annual Growth (per cent) } \\
\hline $\begin{array}{l}\text { Food, Beverages \& } \\
\text { Tobacco }\end{array}$ & - & 6.3 & 3.4 & 6.4 & 3.1 & 0.5 \\
\hline Clothing \& Footwear & - & 19.7 & 23.3 & 5.0 & 5.6 & 5.2 \\
\hline $\begin{array}{l}\text { Gross Rent, Fuel \& } \\
\text { Power }\end{array}$ & - & 3.8 & 3.8 & 4.7 & 4.3 & 5.9 \\
\hline $\begin{array}{l}\text { Furniture, Furnishing } \\
\text { Etc. }\end{array}$ & - & 15.1 & 17.1 & 16.1 & 12.9 & 13.5 \\
\hline $\begin{array}{l}\text { Medical Care \& } \\
\text { Health Services }\end{array}$ & - & 8.8 & 8.7 & 4.5 & 6.9 & 8.9 \\
\hline $\begin{array}{l}\text { Transport \& } \\
\text { Communication }\end{array}$ & - & 5.2 & 8.1 & 7.4 & 9.2 & 14.2 \\
\hline $\begin{array}{l}\text { Recreation, Education } \\
\text { \& Cultural Services }\end{array}$ & - & 11.0 & 8.4 & 9.8 & 11.9 & 6.4 \\
\hline $\begin{array}{l}\text { Miscellaneous Goods } \\
\text { \& Services }\end{array}$ & - & 20.2 & 21.2 & 28.6 & 20.2 & 15.9 \\
\hline $\begin{array}{l}\text { Total Private } \\
\text { Consumption } \\
\end{array}$ & - & 8.4 & 8.5 & 9.1 & 7.6 & 7.4 \\
\hline \multicolumn{7}{|c|}{ Share of Total (Per cent) } \\
\hline $\begin{array}{l}\text { Food, Beverages \& } \\
\text { Tobacco }\end{array}$ & 40.0 & 39.2 & 37.4 & 36.4 & 34.9 & 32.6 \\
\hline Clothing \& Footwear & 6.6 & 7.3 & 8.3 & 8.0 & 7.9 & 7.7 \\
\hline $\begin{array}{l}\text { Gross Rent, Fuel \& } \\
\text { Power }\end{array}$ & 13.8 & 13.2 & 12.7 & 12.2 & 11.8 & 11.6 \\
\hline $\begin{array}{l}\text { Furniture, } \\
\text { Furnishing, etc }\end{array}$ & 3.4 & 3.6 & 3.9 & 4.1 & 4.3 & 4.6 \\
\hline $\begin{array}{l}\text { Medical Care \& } \\
\text { Health Services }\end{array}$ & 5.0 & 5.0 & 5.0 & 4.8 & 4.7 & 4.8 \\
\hline $\begin{array}{l}\text { Transport \& } \\
\text { Communication }\end{array}$ & 19.3 & 18.7 & 18.7 & 18.4 & 18.6 & 19.8 \\
\hline $\begin{array}{l}\text { Recreation, Education } \\
\text { \& Cultural Services }\end{array}$ & 3.0 & 3.0 & 3.0 & 3.1 & 3.2 & 3.2 \\
\hline $\begin{array}{l}\text { Miscellaneous Goods } \\
\text { \& Services }\end{array}$ & 8.9 & 9.9 & 11.1 & 13.0 & 14.6 & 15.7 \\
\hline $\begin{array}{l}\text { Total Private } \\
\text { Consumption }\end{array}$ & 100.0 & 100.0 & 100.0 & 100.0 & 100.0 & 100.0 \\
\hline
\end{tabular}

Source: Economic Survey of India, 2011. 
The rebound in demand-side GDP in 2009-10 was also explained by the two and was obtained in the face of reduced levels of contribution to growth from private final consumption expenditure. A decomposition of the growth in private final consumption expenditure indicates that the sub-group food, beverages and tobacco with a share of over 30 per cent in private final consumption Expenditure fell sharply in terms of growth in both 2008-09 and 2009-10; this sub-group and the sub-group furniture and furnishings were the only two that had decelerated in terms of growth, year-on-year (Table 1.4).

\section{SAVING AND INVESTMENT}

\section{Movements in Public-Sector Savings and Corporate Investment :}

The (Central Statistics Office) CSO's Quick Estimates for 2009-10 placed gross domestic savings at 33.7 per cent of the GDP at current market prices (savings rate). The savings rate for 2008-09 was also revised from 32.5 per cent to 32.2 per cent. With private-sector savings more or less static, it was the savings of the public sector (essentially public enterprises) that went up from a revised level of 0.5 per cent in 2008-09 to 2.1 per cent in 2009-10 (Table 1.5). Private-sector savings had remained sticky in the range of 30.1 per cent to 31.9 per cent in the last six years and seemingly the global crisis had no significant impact.

Table 1.5: Ratio of Savings and Investment to GDP (in per cent at current market prices)

\begin{tabular}{|l|c|c|c|c|c|c|}
\hline & $\begin{array}{c}\mathbf{2 0 0 4 -} \\
\mathbf{0 5}\end{array}$ & $\begin{array}{c}\mathbf{2 0 0 5 -} \\
\mathbf{0 6}\end{array}$ & $\begin{array}{c}\mathbf{2 0 0 6}- \\
\mathbf{0 7}\end{array}$ & $\begin{array}{c}\mathbf{2 0 0 7 -} \\
\mathbf{0 8}\end{array}$ & $\begin{array}{c}\mathbf{2 0 0 8 -} \\
\mathbf{0 9}^{\mathrm{PE}}\end{array}$ & $\begin{array}{c}\mathbf{2 0 0 9 -} \\
\mathbf{1 0}^{\mathbf{}}\end{array}$ \\
\hline Gross Domestic Saving & 32.4 & 33.5 & 34.6 & 36.9 & 32.2 & 33.7 \\
\hline Public Sector & 2.3 & 2.4 & 3.6 & 5.0 & 0.5 & 2.1 \\
\hline Private Sector & 30.1 & 31.0 & 31.0 & 31.9 & 31.7 & 31.6 \\
\hline Household Sector & 23.6 & 23.5 & 23.2 & 22.5 & 23.8 & 23.5 \\
\hline Financial Saving & 10.1 & 11.9 & 11.3 & 11.7 & 10.8 & 11.8 \\
\hline Saving in Physical Assets & 13.4 & 11.7 & 11.9 & 10.8 & 13.1 & 11.7 \\
\hline Private Corporate Sector & 6.6 & 7.5 & 7.9 & 9.4 & 7.9 & 8.1 \\
\hline $\begin{array}{l}\text { Gross Capital Formation } \\
\text { (Investment) }\end{array}$ & 32.8 & 34.7 & 35.7 & 38.1 & 34.5 & 36.5 \\
\hline Public Sector & 7.4 & 7.9 & 8.3 & 8.9 & 9.5 & 9.2 \\
\hline Private Sector & 23.8 & 25.2 & 26.4 & 28.1 & 24.6 & 24.9 \\
\hline Corporate Sector & 10.3 & 13.6 & 14.5 & 17.3 & 11.5 & 13.2 \\
\hline Household Sector & 13.4 & 11.7 & 11.9 & 10.8 & 13.1 & 11.7 \\
\hline
\end{tabular}




\begin{tabular}{|l|c|c|c|c|c|c|}
\hline $\begin{array}{l}\text { Gross fixed Capital } \\
\text { Formation }\end{array}$ & 28.7 & 30.3 & 31.3 & 32.9 & 32.0 & 30.8 \\
\hline Stocks & 2.5 & 2.8 & 3.4 & 4.0 & 2.0 & 3.3 \\
\hline Valuables & 1.3 & 1.1 & 1.2 & 1.1 & 1.3 & 1.7 \\
\hline Saving-investment Gap & & & & & & \\
\hline Public Sector & -5.1 & -5.5 & -4.7 & -3.9 & -9.0 & -7.0 \\
\hline Private Sector & 6.3 & 5.8 & 4.6 & 3.8 & 7.1 & 6.7 \\
\hline
\end{tabular}

Source: Economic Survey of India, 2011.

Gross capital formation, as a proportion of the GDP at current market prices (investment rate) grew rapidly in the period 2004-05 to 2007-08. This reflected the process of fiscal consolidation undertaken by the Centre and the States, which allowed the economy to reap rich dividends in the form of higher investment rates and thus higher GDP growth rate. Investment rate was placed at 36.5 per cent in 2009-10, up from the crisis-affected levels of 34.5 per cent in 2008-09. However, gross fixed capital formation had not picked up in 2009-10. The fall in investment rate in 2008-09 was mostly due to its fall in the private sector, particularly the corporate sector. In 2009-10, as per the Quick Estimates, there has been a pickup in corporate -sector investment; household-sector investment that had shot up in 2008-09 changed tack and is back to pre-crisis levels. Thus the impact of the crisis in 2008-09 was manifest mainly in the levels of changes in stocks, which recovered in 2009-10. However, as per the Quick Estimates, gross fixed capital formation is placed at 30.8 per cent in 2009-10, which is a deceleration on a year-on-year basis.

\section{Savings-Investment Gap Narrows:}

The overall savings-investment gap that was implicit in these estimates was 2.3 per cent in 2008-09 and 2.8 per cent in 2009-10. The gap in terms of sectors indicated a widening of the public-sector balance in 2008-09 to - 9.0 per cent, which subsequently moderated to -7.0 per cent in $2009-10$. This reflected the expansionary polices and was partly made up by the upward shift in the private-sector savings-investment balance on the component side and on the macroeconomic side reflected relatively stronger domestic demand vis-à-vis external demand. While the expansionary fiscal stance was considered apposite given the level of demand slowdown arising from fall in investment, going forward, the need to deepen the process of fiscal consolidation that has resumed in the Budget for 2010-11 cannot be overemphasized. 
Table 1.6: Sectoral Investment Growth Rates at 2004-05 Prices

\begin{tabular}{|l|c|c|c|c|c|}
\hline & \multicolumn{5}{|c|}{ Rate of Growth of GCF } \\
\cline { 2 - 6 } & $\begin{array}{c}\mathbf{2 0 0 5 -} \\
\mathbf{0 6}\end{array}$ & $\begin{array}{c}\mathbf{2 0 0 6} \\
\mathbf{0 7}\end{array}$ & $\begin{array}{c}\mathbf{2 0 0 7 -} \\
\mathbf{0 8}\end{array}$ & $\begin{array}{c}\mathbf{2 0 0 8}- \\
\mathbf{0 9}\end{array}$ & $\mathbf{2 0 0 9 - 1 0}$ \\
\hline Agriculture, Forestry \& Fishing & 13.8 & 4.7 & 15.8 & 22.5 & 3.7 \\
\hline Agriculture & 13.9 & 4.2 & 17.0 & 23.9 & 3.4 \\
\hline Forestry \& Logging & 30.8 & 13.4 & -20.2 & -4.0 & -13.5 \\
\hline Fishing & 9.5 & 9.5 & 9.5 & 9.6 & 9.5 \\
\hline Mining \& quarrying & 40.0 & 15.6 & 13.3 & -13.4 & 62.1 \\
\hline Manufacturing & 17.6 & 16.6 & 29.5 & -31.6 & 34.8 \\
\hline Registered & 39.3 & 11.0 & 37.3 & -27.0 & 25.2 \\
\hline Unregistered & -36.7 & 47.4 & -2.6 & -58.8 & 134.1 \\
\hline Electricity, Gas \& Water Supply & 21.3 & 18.1 & 11.4 & 12.3 & 3.5 \\
\hline Construction & 5.7 & 66.3 & 20.4 & -24.7 & 16.8 \\
\hline Trade, Hotel \& Restaurants & 26.7 & 40.3 & -17.7 & 29.9 & -27.4 \\
\hline Trade & 22.6 & 44.9 & -22.8 & 35.8 & -32.7 \\
\hline Hotels \& Restaurants & 49.2 & 19.5 & 10.4 & 7.0 & -1.0 \\
\hline $\begin{array}{l}\text { Transport, Storage \& } \\
\text { Communication }\end{array}$ & 20.1 & -7.4 & 25.9 & 37.6 & 0.9 \\
\hline Railways & 14.6 & 12.9 & 13.7 & 22.5 & 9.3 \\
\hline Transport by Other Means & 12.8 & -14.8 & 29.6 & 12.8 & -8.9 \\
\hline Storage & -285.7 & 14.9 & 7.1 & 62.4 & -1.5 \\
\hline Communication & 33.2 & -7.8 & 30.1 & 86.7 & 6.6 \\
\hline $\begin{array}{l}\text { Financing, Insurance, Real Estate \& } \\
\text { Business Services }\end{array}$ & 6.2 & -0.4 & 10.6 & 41.0 & -3.3 \\
\hline Banking \& Insurance & 70.4 & 61.8 & -6.8 & -5.0 & -26.1 \\
\hline $\begin{array}{l}\text { Real Estate, Ownership of Dwellings } \\
\text { \& Business Services }\end{array}$ & 4.3 & -3.3 & 12.0 & 44.0 & -2.3 \\
\hline $\begin{array}{l}\text { Community, Social \& Personal } \\
\text { Services }\end{array}$ & 19.6 & 12.3 & 18.4 & -3.6 & 12.3 \\
\hline Public Administration \& Defence & 17.3 & 14.0 & 13.4 & 3.3 & 11.1 \\
\hline Other Services & 22.7 & 10.2 & 25.0 & -11.9 & 14.0 \\
\hline Total & 17.0 & 15.3 & 17.7 & -3.9 & 12.2 \\
\hline
\end{tabular}

Source: Economic Survey of India, 2011.

The rates of investment across sectors indicated the varying levels of impact of the crisis and recovery. Growth in investment in the agriculture sector, even after the revisions, was strong in 2007-08 and 2008-09, but appeared to have dipped in 2009-10 (Quick Estimates) with growth at 3.7 per cent (Table 1.6). Forestry and logging continues to decline--a process that began in 2007-08 but 
more sharply in 2009-10. Sectoral investment in fishing was relatively static. Investment in two sectors-mining and quarrying and construction has picked up sharply in 2009-10. The following sectors evinced a decelerating trend in 2009-10: electricity, gas and water supply; railways; and communications. There was a decline in the rates of investment in trade, hotels, and restaurants with trade declining sharply; for the third year banking and insurance declined and real estate declined on base effect.

\section{PRODUCTION AND SUPPLY}

\section{Agriculture is Critical for Macroeconomic Stability and Sustained Growth:}

The growth of agriculture and allied sectors continues to be a critical factor in the overall performance of the Indian economy. It might be recalled that this sector had grown in excess of 5.0 per cent on average annual basis in the triennium ending 2007-08 when real GDP grew in excess of 9 per cent. This sector accounted for 12.7 per cent of the real GDP in the first half of 2010-11. Despite experiencing the most deficient south-west monsoon since 1972 and a significant fall in the levels of kharif foodgrain production in 2009-10, the growth in agriculture marginally recovered to 0.4 per cent primarily due to a good rabi crop. Several measures taken in advance by the Government for raising the rabi crop output had the desired effect. The farming sector was also broadly supported by more remunerative prices and, earlier, by the waiver of loans and other measures taken.

For four consecutive years from 2005-06 to 2008-09, foodgrains production registered a rising trend and touched a record level of 234.47 million tonnes in 2008-09. The production of foodgrains declined to 218.20 million tonnes during 2009-10 ( $4^{\text {th }}$ Advance Estimates) due to the long spells of drought in various parts of the country in 2009. The productivity of almost all the crops suffered considerably which led to decline in their production in 2009. As per the $1^{\text {st }}$ Advance Estimates (covering only kharif crops), production of kharif foodgrains during 2010-11 is estimated at 114.63 million tonnes which is lower than the target of 125.31 million tonnes but higher than kharif foodgrain production of 103.84 million tonnes recorded during 2009-10 (4 $4^{\text {th }}$ Advance Estimates). The shortfall in the estimated kharif foodgrain production compared to the target in 2010-11 is mainly due to drought conditions reported in major rice-producing areas in the country. 
The country has made great strides in increasing foodgrains production since the mid-1960s. Today India ranks high in the production of various commodities such as milk, wheat, rice, fruits, and vegetables. However, the agriculture sector in India is at a crossroads with rising demand for food items and relatively slower supply response in many commodities resulting in frequent spikes in food inflation. The technological breakthrough achieved in the 1960s is gradually waning. The need for a second green revolution is being recognized more than ever before. There is need to significantly step up both private and public investment in the agriculture sector to ensure sustained growth so as to achieve the target growth of around 4 per cent per annum. The rise in prices of agricultural produce would in part help incentivize production; the moot question remains what proportion of the rise accrues to the producer and what proportion gets appropriated by middlemen. The creation of more direct farm-to-fork supply chains in food items across the country would be critical in incentivizing the farmer with higher producer prices and at the same time would lower the prices for end-consumers.

\section{Infrastructure:}

Overall, the infrastructure sector has had a mixed bag of performances; some like telecommunications have done exceedingly well and in some others there has been less than targeted achievement. During 2007-08 to 2009-10, capacity addition has been lower than target in power, roads (NHDP), new railway lines, and doubling of railway lines. The sub-sectors where physical achievements have been above or close to targets are telecommunications, villages electrified under the Rajiv Gandhi Grameen Vidyutikaran Yojana (RGGVY), railway lines electrification, railway gauge conversion, and new and renewal of roads construction under the Pradhan Mantri Gram Sadak Yojana (PMGSY). The investment in infrastructure has reached 7.18 per cent of the GDP in 2008-09 and is expected to increase to 8.37 per cent in the terminal year of the Eleventh Plan. Rapid reduction of the infrastructure deficit holds the key to competitiveness in an increasingly globalized economic environment.

\section{Service Sector :}

The services sector has played a dominant role in the Indian economy with a 57.3 per cent share in the GDP; a growth of 10.1 per cent in 2009-10; a high share in FDI equity inflows with the financial and non-financial services category alone contributing 21 per cent during April 2000 to November 2010; and a 35 
per cent share in total exports with 27.4 per cent export growth in the first half of 2010-11. A comparison of shares of the services sector in the GDP of different States and Union Territories shows that the services sector is also the dominant sector in most of the States of India.

High-growth services categories are financing, insurance, real estate, and business services and transport, storage, and communication with the latter overtaking the former in 2009-10 with a high growth of 15 per cent. Growth of trade, hotels, and restaurants which slowed down in 2008-09 has recovered moderately in 2009-10. Among the sub-categories, in 2008-09, double- digit growth was registered by communications ( 25.7 per cent), public administration and defence (22.1 per cent), banking and insurance (13.9 per cent), and storage (11.6 per cent). Negative growth was registered only by hotels and restaurants (-3.5 per cent). Among business services, the most important categories are computerrelated service; and the category consisting of many services like research and development (R\&D) services, market research, business and management consultancy, architectural engineering, and advertising., with shares in the GDP of 3.26 per cent and 0.88 per cent respectively. While computer-related services which grew by 21.2 per cent in 2008-09 registered a moderate growth of 5.2 per cent in 2009-10 due to the global crisis, R\&D services registered good growth of 19.6 per cent and 19.9 per cent in both 2008-09 and 2009-10 respectively.

Among other services, the two important services are education and medical health in terms of relative share of the GDP; they had growth rates of 13.9 per cent and 5.3 per cent in 2009-10 respectively. While total services including construction grew by 9.7 per cent, total services excluding construction grew by 10.1 per cent in 2009-10. In 2010-11(Advance Estimates), they grew by 9.4 per cent and 9.6 per cent respectively. The outlook for the services sector which had slightly dimmed due to the fallouts of the sub-prime crisis in US and the global financial crisis has once again brightened. Recent business performance indicators of different service firms in the different services also support this healthy prognosis. Even during the crisis years, annual services growth has been around the 10 per cent mark which it has maintained since 2005-06. This is in contrast to the overall GDP growth which fell to 6.8 per cent in 2008-09 from 9.3 per cent in 2007-08.

\section{External Sector Development :}

The global economy was estimated to have grown rapidly in 2010 by 5.0 per cent according to the update of the WEO (25 January 2011); which was one of the 
highest rates of growth in recent years and compares favourably with the robust levels in the pre-crisis period. Growth in emerging economies remains strong, while advanced countries are growing slowly and facing uncertainty with large fiscal deficit and high public debt and unemployment levels. This indicated the two-paced nature of the global growth process in the current conjuncture. While growth in 2010 was partly a rebound from weak levels in 2009, the estimate for 2011 and 2012 at about 4.5 per cent indicated the prospects. The Market Update of the Global Financial Stability Report of the IMF (January 2011) observed that global financial stability is still to be assured and significant policy challenges remain to be addressed: slow progress in the as yet incomplete balance sheet restructuring process; interaction between the banking and sovereign credit risks in the euro area; and need for more regulatory reforms to the financial sector to anchor stability. In several emerging market economies (EMEs), however, there has been surge in capital inflows with the associated risk of bubbles in asset and credit markets. There have also been signs of rising inflation, in response to strong global demand, combined with supply constraints.

\section{CONCLUSION}

After decades of unremarkable growth following independence, Indian economy took off in the eighties and continued to grow well into the nineties. While a number of economists have suggested theories to explain this growth phenomenon, empirical studies that attempt a numerical growth accounting of India is at best limited.

Based on the performance of the economy over the last five years and analysis of the underlying trends of critical variables, India's real GDP is expected to grow by 9 per cent (+/- 0.25) in 2011-12. The Indian economy had grown at above 9 per cent for three consecutive years starting in 2005-06.So the economy is expected to revert to pre-crisis growth levels next year. The country's savings and investment rates had gone down a little during 2008-09 because of the deliberate decision by the Government to encourage consumption as an antidote to the economic downturn. The latest data on savings and investments, which pertain to 2009-10, show that these rates have turned around. In 2009-10 the savings rate was 33.7 per cent, up from the previous year's 32.3 per cent, and the investment rate had also risen and stood at 36.5 per cent. India's incremental capital-output ratio (ICOR) is estimated to be 4.1 for the Eleventh Plan. Given that the economy still has excess capacity, these two indicators lead to a projection of GDP growth just short of 9 per cent. Since savings and investments now show a positive momentum and the Government is implementing a gradual exit from 
the stimulus package, the savings and investment rates are likely to rise further. Hence it is expected that the economy's growth will breach the 9 per cent mark in 2011-12.

It is known that once an economy begins to operate close to its capacity, the savings and investment rates are no longer such effective drivers of GDP growth. Growth then depends much more on skill development and innovative activity in the country. Fortunately, there is awareness of this in India and efforts are afoot in terms of budgetary allocation and actual initiatives to boost the development of skill and human capital. Innovative activity in a nation is difficult to measure but, judging by patenting activity, there seems to be a pickup in research and innovation in India. Patent applications used, traditionally, to be few and far between. There is, however, a sharp rise in this over the last few years. In 2004-05, 17,466 patents were filed and 1911 granted. In contrast, in 2008-09, 36,812 patents were filed and 16,061 granted. There are also initiatives to bolster India's higher education system, including universities, institutes of technology, and centres of research. It is expected that these initiatives will gather steam and more than make up for eventually waning power of the savings rate as a driver of economic growth. As a consequence, the next two decades should see the Indian economy growing faster than it has done any time in the past and also faster than the growth in the next two years.

\section{REFERENCES}

1. Acharya, Shankar, 2001. India's Macroeconomic Management in the Nineties (New Delhi, Indian Council for Research on International Economic Relations)

2. Amaral, Pedro \& Macgee, James (2002), The Great Depression in Canada and the United States: A Neoclassical Perspective, Review of Economic Dynamics 5(1), pp. 45-72.

3. Economic Reform and Globalization, Public Economics 0412007, Economics Working Paper Archive Econ WPA.

4. Economic Survey of India, 2010-11.

5. Government of India, 1984. Committee on Trade Policies. (New Delhi, Ministry of Commerce)

6. Nayar, Baldev Raj, 2001. Globalization and Nationalism: The Changing Balance in India's Economic Policy, 1950-2000. (London, Sage Publications)

7. Narayan Murthy, N.R (2002) "The Impact of Economic Reforms on the HiTech Industry in India: A Case Study of Infosys", The Indian Economy Conference, Cornell University, April 19-20, 2002.

8. Rodrik, Dani, 1996. "Understanding economic policy reform," Journal of 
Economic Literature, vol. XXXIV, March, pp. 9-41.

9. Sachs, Jefrey (2002) "Growth Prospects of the Indian Economy" The Indian Economy Conference, Cornell University, April 19-20, 2002.

10. Subramanian, Arvind and Rodrick, Dani "From Hindu Growth Productivity Surge: The Mystery of the Indian Growth Transition," CEPR Discussion Papers 4371, C.E.P.R. Discussion Papers. 
Овај рад је примљен 20.11.2015. а на састанку редакције часописа прихваћен за штампу 02.12.2015. године. 